\title{
Status of research on the development of management tactics and strategies for the spruce bud moth in white spruce plantations
}

\author{
by Jean J. Turgeon ${ }^{1,2}$
}

The spruce bud moth, Zeiraphera canadensis, represents an economic threat to white spruce, Picea glauca, managed for lumber production in eastern Canada. Larvae feed on developing shoots. Larval feeding on the leader adversely affects tree form and reduces vertical growth. Although the economic impact of this insect has not been critically established, it is feared that this damage could decrease the quality and value of the lumber produced and could delay harvest by several years. This paper reviews the information on the spruce bud moth life cycle, behaviour, impact, sampling and monitoring, and the possible management tactics investigated to date.
La tordeuse de l'épinette, Zeiraphera canadensis, représente une menace sérieuse pour les plantations d'épinettes blanches, Picea glauca, destinées à la production de bois de sciage. Les larves de ce ravageur se nourissent du feuillage de l'année courante. Celles qui s'attaquent à la flèche terminale, auront un effet négatif sur la forme et la croissance de l'arbre. Il est possible que ce type de dégât ait pour effet de diminuer la qualité et la valeur du bois produit et possiblement d'en retarder la coupe. Ce document présente une revue de l'information disponible à ce jour sur le cycle vital, le comportement, les dégâts, l'échantillonnage et le dépistage de cet insecte de même que les méthodes de lutte qui ont fait l'objet d'études.

\section{Introduction}

Spruce bud moth, Zeiraphera canadensis Mutuura and Freeman, eggs and larvae have been collected from most North American spruces (Picea spp. $)^{3}$, but occur most frequently on white spruce, $P$. glauca (Moench) Voss (Prentice 1965; Mutuura and Freeman 1966; Turgeon 1986). Populations of $Z$. canadensis have probably always been present in small plantations and natural forests across Canada (MacAndrews 1927; Magasi 1982; Martineau 1985; Martineau and Ouellette 1965; Mutuura and Freeman 1966; Prentice 1965; Schooley 1983) and the northeastern part of the United States (Drooz 1985; Holmes and Osgood 1984), although severe damage has been reported solely in eastern Canada, in the Baie des Chaleurs area (MacAndrews 1927; McLeod and Blais 1961; Pilon 1965; Magasi 1982, 1983, 1984; Bonneau et al. 1986). The spruce bud moth was first considered a pest of economic importance around $1980^{4}$ when more than 16,000 ha of white spruce plantations (a corporate investment of more than $\$ 16,000,000$ ), managed intensively for lumber production, were infested. Feeding by $Z$. canadensis larvae in these plantations resulted in a significant increase in the number of trees with multiple leaders and inconsistent patterns of leader growth. Although no studies on the economic impact of this insect were available at the time, forest managers feared that this damage could reduce the quality and value of the lumber produced (Neilson 1985) and delay harvest by several years. Such impacts appeared critical, especially in provinces such as New Brunswick whose wood supply depends heavily on the performance of new forests (Carrow 1985).

In 1982, studies were initiated to investigate means of controlling the spruce bud moth and preventing damage to

\footnotetext{
${ }^{\text {IForestry Canada - Forest Pest Management Institute, P.O. Box 490, Sault }}$ Ste. Marie, Ontario P6A 5M7.

${ }^{2}$ Recommendations for pesticide use in this publication are intended as suggestions only. Any application of a pesticide must be in accordance with directions printed on the product label of that pesticide as prescribed under the Pest Control Products Act. Always read the label. A pesticide should also be recommended by provincial authorities. Consult them for specific advice.
}

leaders. The ecology and behaviour were examined to identify possible control periods, tactics, and strategies. Damage was described and categorized to evaluate its potential impact on white spruce growth and form, sampling and monitoring tools were developed to detect the presence and assess the densities of bud moth populations, and several experimental and operational control methods were tested under laboratory and field conditions. This paper provides an overview of this research.

\section{Taxonomy, Life History and Behaviour}

After reviewing the taxonomy of North American Zeiraphera spp. adults, Mutuura and Freeman (1966) concluded the spruce bud moth, referred to as $Z$. ratzeburgiana (Ratzeburg) by North American authors (MacAndrews 1927; Miller 1950; Mackay 1959; McLeod and Blais 1961; Pilon 1965; Prentice 1965), was a new species, Z. canadensis. The first species, Z. ratzeburgiana, a pest affecting Norway spruce in Europe (Viktorovskaya 1976), does not occur in Canada (Mutuura and Freeman 1966). The most useful morphological characteristic used to separate the spruce bud moth from other lepidopterous larvae that feed on white spruce foliage is the absence of an anal comb on $Z$. canadensis larvae (Miller 1950; Mackay 1959).

The spruce bud moth has one generation per year and overwinters as a diapausing egg (Régnière and Turgeon 1989), between the scales located at the base of the current year's growth (Pilon 1965). Hatching usually occurs in May and is well synchronized with bud burst of white spruce in New Brunswick (Turgeon 1986). There are four larval instars (Pilon 1965). Larval development is usually completed within

\footnotetext{
${ }^{3}$ Reports that it may also infest western hemlock and some firs (Prentice 1965) are doubtful, as no new collections have been reported since the taxonomy of the group has been revised.

${ }^{4}$ Interestingly, the beginning of this outbreak also appears to coincide with the general decline of the spruce budworm, Choristoneura fumiferana (Clem.) in that area (Bonneau et al. 1986; Magasi 1985). Important spruce bud moth damage had been reported in the early 60's (McLeod and Blais 1961; Pilon 1965; Magasi 1985), immediately following the end of the spruce budworm infestation.
} 
20-25 days (Turgeon 1985). Fourth-instar larvae drop to the ground and crawl into the litter where they web together any material to form a cocoon. Pupation occurs after cocoon formation. Adults emerge about three weeks later, and the flight period generally lasts two to three weeks. Detailed information on Z. canadensis biology ${ }^{5}$ and behaviour can be found in MacAndrews (1927), Pilon (1965), Turgeon (1985), Turgeon et al. (1987) and Hébert (1990).

The relationship between the phenological development of spruce bud moth larvae and that of white spruce shoots was established in New Brunswick using descriptive indices for both insect and shoot development (Turgeon 1986).

\section{Damage}

Damage caused by each instar has been described by Pilon (1965) and Turgeon (1985). First- and second-instar larvae mine needles of recently burst buds and cause little damage. Third- and fourth-instar larvae feed on the proximal end of needles as well as on meristematic tissue (Graham and Knight 1965) leaving a characteristic scar. This scar is apparent two to three weeks after larvae have dropped to the ground to pupate and remains visible for at least two years. Larval feeding upon the meristematic tissue often weakens, and sometimes destroys, the stem. Weak stems remain susceptible to breakage by heavy rains, strong winds, and birds until shoot hardening is completed. Although most late-instar larvae concentrate their attack in the upper crown ${ }^{6}$ and on leaders (Turgeon and Régnière 1987), leaders are not always destroyed, making it difficult to assess the overall economic impact of $Z$. canadensis on lumber production.

The loss of lateral shoots and needles could have an impact on volume increase. Nevertheless, current attempts at establishing an economic injury level for lumber production of white spruce are focused primarily on the damage occurring to the leader and are based on loss of vertical growth and form. In 1984, a survey of three plantations of white spruce near St. Leonard, N.B. was conducted and the number of multiple leaders on trees with and without evidence of $Z$. canadensis larval feeding was compared. This survey revealed that $67 \%$ of trees with a broken leader, or with evidence of larval feeding $(N=201)$, produced multiple leaders the following year compared with $17 \%$ for trees without evidence of larval feeding $(N=128)$. The position of larval feeding on unbroken leaders was also important in inducing the production of multiple leaders. With this information, four damage categories were defined, each with an increasing probability of inducing the production of multiple leaders, and were used to assess $Z$. canadensis impact on growth and form of white spruce. These categories are: no damage on leader $=(0)$; larval feeding has occurred on leader but the scar is at least $5 \mathrm{~cm}$ away from the apical buds $=(1)$; larval feeding has occurred within $5 \mathrm{~cm}$ of the apical buds $=(2)$, and larval feeding has resulted in a broken leader or the destruction of the apical bud $=(3)$. Currently, the relative efficacy of most control methods being investigated is

\footnotetext{
${ }^{5} \mathrm{~A}$ rearing method has been developed and is available upon request from the author.

${ }^{6}$ Most eggs, first- and second-instar larvae are found in the middle of the crown but a dispersal by late second- and early third-instar larvae outward and upward in the canopy results in most third and fourth-instar larvae occurring in the upper third of the crown (D. Quiring, Department of Forest Resources, University of New Brunswick, unpubl. data).
}

assessed by determining the number of trees in each of these four categories and by calculating, for the treated and untreated plots, the following damage index:

Damage Index $=\frac{\left(1 \times t_{1}\right)+\left(2 \times t_{2}\right)+\left(3 \times t_{3}\right)}{t_{0}+t_{1}+t_{2}+t_{3}}$

where $0,1,2,3$ indicate the category of damage, and $t_{0}$, $t_{1}, t_{2}, t_{3}$ represent the number of trees within each class. Although the relationships between mean larval density of Z. canadensis in a plantation and the proportion of trees in each damage category are not fully established, an index of 1 or higher usually indicates that more than $10 \%$ of the leaders in the plantation are broken. These relationships could be used to decide whether control action is warranted until results from more detailed studies assessing the effects of Z. canadensis on white spruce growth, form, and volume are available and an economic threshold is established.

\section{Sampling and Monitoring}

Sampling methods and monitoring tools were needed to evaluate spruce bud moth populations and to assess the efficacy of management tactics being developed.

\section{(a) Eggs and Larvae}

One $15-\mathrm{cm}$ branch, measured from the scales of the branch's apical growth and taken from the upper crown of each tree, has been used as a sampling unit for $Z$. canadensis eggs and larvae (Turgeon and Régnière 1987). A new unit may have to be developed because a variable amount of within tree redistribution of second-instar larvae takes place each year (Turgeon 1985). Helson et al. (1989) used a $45-\mathrm{cm}$ branch sample, which provided less variation in pre- and post-spray samples, but took much longer to process. Sequential sampling plans with one (Turgeon and Régnière 1987) and two (Régnière et al. 1988) critical levels of larval density have also been developed. The Ministère de l'Energie et des Ressources du Québec is the only provincial agency to use one of these plans - the latter one - to monitor $Z$. canadensis changes in geographical distribution, extent of damage, and fluctuations in population levels (Bonneau $e t$ al. 1986; Boulet 1987; Bordeleau et al. 1988, 1989). In forecasting population levels for the following year, they sample 25 branches per plantation ${ }^{7}$ after spruce bud moth females have completed oviposition and soak the scales of each branch in sodium hydroxide to remove egg clusters, which are counted under a microscope (C. Bordeleau, Ministère de l'Energie et des Ressources du Québec, pers. comm.).

\section{(b) Adults}

Electroantennogram responses, followed by field screening tests of candidate sex attractants, indicated (E)-9-tetradecenyl acetate (E9-14:Ac) is attractive to $Z$. canadensis males (Turgeon and Grant 1988). This compound was later identified as its primary sex pheromone component (Silk et al. 1989). Traps located in the upper crown of white spruce and baited with $10 \mu \mathrm{g}$ of E9-14:Ac were found to be most effective in trapping males (Turgeon and Grant 1988; Lavallée and Morissette 1988). No consistent differences in the number

\footnotetext{
${ }^{7}$ This sample size is sufficient to estimate spruce bud moth densities of $\geq 2$ larvae/ $15 \mathrm{~cm}$ branch with a precision of 0.3 at the $68 \%$ confidence level (Turgeon and Régnière 1987).
} 
of males caught were obtained in a comparison of two nonsaturating traps (Multi-Pher ${ }^{\circledR}$ and Uni-trap ${ }^{\circledR}$ ) and one sticky trap (Pherocon $1 \mathrm{CP}^{\circledR}$ ) (Turgeon and Grant 1988). This lack of consistency in trap capture is probably associated with trap location. Indeed, traps hung in white spruce trees caught significantly more males than those hung on poles between trees (Turgeon and Grant 1988). Variability in traps hung in trees was extremely high. These results suggest that additional research aimed at reducing variability in trap captures is needed.

The influence of temperature, precipitation and time of year on the rate of capture was examined. Typically, the rate of capture is positively correlated with temperature and negatively related with precipitation (Lavallée et al. 1988).

The Forest Pest Management Institute and the Ministère de l'Energie et des Ressources du Québec are cooperatively investigating the possibility of developing a sex pheromonebased monitoring system and establishing the relationship between pheromone trap catches of adults and egg density. The accuracy of this relationship for predicting population trends and damage intensity the following year will determine whether it will replace or complement the egg mass survey currently being used in Québec.

\section{Control}

J.D. Irving Ltd., Woodlands Division, first attempted to control the spruce bud moth in 1980 by aerial application of chemical (Dylox ${ }^{\circledR}$, Matacil 180F ${ }^{\circledR}$, Sumithion ${ }^{\circledR}$, Orthene ${ }^{\circledR}$, Zextran UCZF 19 ${ }^{\circledR}$ ) and biological (Futura XLV ${ }^{\circledR}$, SAN $415^{\circledR}$, Thuricide $48 \mathrm{LV}^{\circledR}$ ) insecticides against third-instar larvae (Kettela 1990), a strategy successful against $C$. fumiferana. These treatments, however, were ineffective in reducing $Z$. canadensis larval populations and preventing leader damage (Kettela 1990; Hartling 1981, 1982). By 1984, this company had written off their oldest plantations for sawlog production (Neilson 1985). By then, studies on the biology of Z. canadensis (Turgeon 1985) had revealed that third-instar larvae feed under needles and scales, and thus are not directly exposed to insecticide sprays.

\section{(a) Windows of Opportunity for Intervention}

There are four periods in which $Z$. canadensis are exposed: (1) at egg hatch, when first-instar larvae crawl toward recently burst buds, (2) as late second or early third instars, when some larvae re-establish in different shoots, (3) as fourth instars, when larvae drop to the litter to pupate and (4) as adults (Turgeon 1985). Because redistribution of second-instar larvae has been found to vary drastically between years, even in sites with similar densities, and because fourth-instar larvae drop to the ground rapidly and without feeding, control efforts have focused primarily on first-instar larvae and adults. Timing of treatments for control of first-instar larvae or adults is critical and is based on an ability to accurately predict egg hatch and female emergence, respectively.

A phenological model was developed and calibrated to simulate the relative abundance of the various immature stages under field conditions (Régnière and Turgeon 1989), but for the purpose of planning the timing of control operations, it is likely that the degree-day requirements estimated for $10 \%$ egg hatch $\left(146 \pm 16^{\circ} \mathrm{C}\right.$ days with a threshold value of $4.4^{\circ} \mathrm{C}$ ) may be favoured (Régnière and Turgeon 1989).
The model developed by Régnière and Turgeon (1989) can also be used to predict the beginning of male emergence. Degree-day requirements for $75 \%$ adult emergence, judged an appropriate target for predicting the onset of oviposition (Turgeon 1985), were estimated at $685 \pm 12^{\circ} \mathrm{C}$ days (Régnière and Turgeon 1989). Pheromone traps baited with E9-14:Ac and located in the upper crown of white spruce were also effective in determining the time the adult flight begins (Turgeon and Grant 1988).

\section{(b) Chemical Insecticides}

1. Treatments against larvae. Typically, first-instar larvae leave the oviposition site and within $30 \mathrm{~min}$ crawl onto a twig and establish in a suitable shoot (Turgeon 1985). Consequently, to be effective in controlling first-instar larvae, an insecticide would require sufficient toxicity to kill larvae while, or shortly after, they crawl toward shoots. The insecticide would also need to have a relatively long residual activity to ensure control of larvae during the entire hatching period, which usually lasts less than a week (Turgeon 1985). Using a bioassay where first-instar larvae were allowed to crawl on treated twigs, the toxicity and residual activity of eight chemical insecticides were assessed under laboratory and greenhouse conditions. These tests demonstrated that permethrin, a pyrethroid, was the only insecticide with a high potency and a long residual activity (Table 1), thus offering the best potential for success under field conditions (Helson et al. 1989). Among the insecticides tested under field conditions, only applications of permethrin at $70 \mathrm{~g}$ /ha with fixed wing aircraft provided an acceptable level of leader protection with $<$ than $10 \%$ of leaders destroyed (Helson et al. 1989). Although this experiment was not replicated, an aerial application of $70 \mathrm{~g} / \mathrm{ha}$ of permethrin with helicopter and a ground application with a backpack mist blower supported these results (B. Helson, Forestry Canada, Forest Pest Management Institute, pers. comm.). In Maine, Holmes and Osgood (1984) applied fenvalarate, another pyrethroid, with ground-spray equipment and obtained similar levels of control and protection. Acceptable leader protection was possible by ground spraying trees with permethrin up to 9 days prior to the beginning of hatching (Helson and Auger, in press).

Although these pyrethroid insecticides are extremely toxic to aquatic invertebrates and vertebrates, their use for aerial application could be limited to sites where no aquatic systems are present or where they could be effectively buffered from

Table 1. Toxicity and residual activity of insecticides screened under laboratory conditions ${ }^{1}$ for their potential to control spruce budmoth, Z. canadensis, first-instar larvae crawling on treated white spruce twigs

\begin{tabular}{lccc}
\hline Insecticide & Concentration & $\begin{array}{c}\text { Relative } \\
\text { potency }^{2}\end{array}$ & $\begin{array}{c}\text { Relative residual } \\
\text { activity }\end{array}$ \\
\hline aminocarb & $180 \mathrm{~g} / \mathrm{L}$ & $(0.28) 6$ & Short \\
azinphos-methyl & $240 \mathrm{~g} / \mathrm{L}$ & $(0.20) 7$ & Long \\
chlorpyrofos & $480 \mathrm{~g} / \mathrm{L}$ & $(1.00) 1$ & Short \\
fenitrothion & $1250 \mathrm{~g} / \mathrm{L}$ & $(0.83) 4$ & Short \\
methomyl & $215 \mathrm{~g} / \mathrm{L}$ & $(0.65) 5$ & Short \\
mexacarbate & $21.6 \%$ & $(0.82) 3$ & Short \\
permethrin & $50 \%$ & $(0.94) 2$ & Long \\
thiodicarb & $500 \mathrm{~g} / \mathrm{L}$ & $(0.12) 8$ & Short \\
\hline
\end{tabular}

${ }^{1}$ Modified from Helson et al. (1989). Potter's tower at 5 dosages: 0.005 , $0.01,0.05,0.1$ and $0.5 \mu \mathrm{g} \mathrm{Al} / \mathrm{cm}^{2}$.

${ }^{2}$ Potency relative to Chlorpyrifos based on parallel line probit analysis. 
the effects of the treatment (Kingsbury and Kreutzweiser 1987; Kreutzweiser and Kingsbury 1987). A petition to register permethrin as a ground spray against $Z$. canadensis has been filed in Canada.

2. Treatments against adults. Aerial application of an insecticide while adults are flying was also investigated, between 1985 and 1989, as a means of providing leader protection for the year following treatment. Optimal efficacy of an adulticide would require that the application be made after most females have emerged, but before they begin ovipositing. Under field conditions, females emerge 1-2 days later than males (Turgeon 1985) and begin oviposition 5-8 days after emergence (Turgeon et al. 1987). Thus, optimal conditions for adulticidal treatments usually occur approximately 6-10 days after the first male has been caught in traps. In 1985 and 1986, an ultra-low volume of fenitrothion (105 g $10.8 \mathrm{~L} / \mathrm{ha}$ ) applied ${ }^{8}$ as an adulticide 9 and 8 days, respectively, after the first male had been caught in one of the three pheromone traps located on-site, reduced egg lay and subsequent larval populations drastically, and provided acceptable levels of protection in the following year (Kettela 1990). If the application is too early, or if adult emergence is longer than usual, a second adulticide spray might be required (Kettela 1990). A petition will be filed to register this insecticide at the above dosage for $Z$. canadensis control.

\section{(c) Growth Regulators}

The effectiveness of three benzoylphenyl urea insect growth regulators (Diflubenzuron, BASF 153-100-50 WP and HOE-00522-20 W/V) in controlling crawling first-instar larvae of $Z$. canadensis, was assessed under field conditions between 1986 and 1988, in Matapédia, Québec. Although application of these growth regulators with a backpack sprayer appeared effective, aerial applications failed to reduce larval populations and leader damage (A. Retnakaran, Forestry Canada, Forest Pest Management Institute, pers. comm.).

\section{(d) Attractants}

The sex pheromone of $Z$. canadensis was dispersed aerially throughout infested plantations during the optimal period, which occurs only a few days after the first male emergence is recorded, in an attempt to disrupt mating and reduce population levels. Progress with this control tactic is currently hindered by the lack of a suitable controlled release formulation, and field trials have been postponed until an adequate formulation is found (P. Silk, Research Productivity Council, New Brunswick, pers. comm.).

\section{(e) Biological Control}

1. Naturally occurring biological control. Natural enemies of $Z$. canadensis are listed in Tables 2 and 3. The records used to construct this list were obtained from the reference after each species name, and from collections made near Bathurst and St. Leonard ir New Brunswick (Turgeon 1985), near St-Léonard de Matapédia, St-Francois d'Assise, and StAlexis de Matapédia, in Bonanventure County, Québec (L. Jobin, Forestry Canada - Quebec Region, unpublished data; Hébert 1990), and in the Pokiok seed orchard, New

\footnotetext{
${ }^{8}$ All sprays with Turbo Trush or Trush Commander aircraft with Micronair AU 3000's or 4000's.
}

Brunswick (Carter 1988). Older names now in synonymy are given directly below the currently used name.

1.1 Eggs. Over the 3-year period of study (Turgeon 1985), the proportion of eggs killed by the minute egg parasitoid, Trichogramma minutum Riley, in various white spruce plantations near St. Leonard, varied between 3 and $36 \%$. Parasitism by T. minutum can reach up to $75 \%$ (D. Ostaff, Dept. Forest Resources, University of New Brunswick, pers. comm.).

During the same period, unknown predators (probably mites) killed up to $30 \%$ of $Z$. canadensis eggs, and this predation appeared constant in each site, irrespective of the density of host eggs. Similar observations were reported by Delucchi et al. (1975), who examined the regulating action of egg predators on populations of the European larch bud moth, $Z$. diniana Guénée.

1.2 Larvae. Most parasitoids of $Z$. canadensis attack larvae, but together they cause little mortality. The rates of larval parasitism in southwestern Quebec were 2.8 and 3.6\%, whereas along the Quebec coast of Baie des Chaleurs in the Gaspé Peninsula, they did not exceed $12.4 \%$ (Pilon 1965). In 1983, larval parasitism near Bathurst and St. Leonard was estimated at 2 and $6 \%(N=425$ and 1500 , respectively). The relative contribution of each species to spruce bud moth mortality appears to vary greatly between regions. In the Gaspé Peninsula, Triclistus podagricus (Gravenhorst) was considered the most important species (Pilon 1965), whereas in New Brunswick, it was found that $53 \%$ of the parasitized hosts were killed by Earinus zeirapherae (Walley), $41 \%$ by Enytus montanus (Ashmead); the remaining 6\% could not be identified. Because knowledge of parasitoid guilds of North American Zeiraphera spp. appears imcomplete when compared to European species, it is essential that long-term studies be initiated to assess the structure and effects of parasitoid guilds on $Z$. canadensis population dynamics under the present forest management practices.

Microscopic examination of spruce bud moth larvae of all instars collected during the study in New Brunswick (Turgeon 1985) failed to detect the presence of viruses $(N=944)$ or protozoa $(N=664)$.

1.3 Pre-pupae and pupae. In his study, Pilon (1965) reported spruce bud moth pupal populations were reduced by approximately $80 \%$, and suggested that predators were probably responsible for this reduction. Similar predation rates were obtained in a small experiment conducted by the author in 1984 near Bathurst. At the beginning of each week, for two consecutive weeks, a group of $250 \mathrm{Z}$. canadensis pupae was placed in a container filled with litter, and left unprotected under a white spruce tree for 1 week. From the first group 53 pupae were recovered ( $80 \%$ predation); only 14 pupae (94\% predation) were recovered from the second group. A total of 245 pupae were recovered from containers excluding only small mammals and 248 from containers excluding all predators. The species of ants and carabids that were observed removing pupae were recorded (Table 3). Equally high predation rates were reported in Matapédia (Hébert 1990) and in the Pokiok seed orchard (Carter 1988). Predation by ants usually occurs between the time larvae fall from the tree and their disappearance in the litter (Carter 1988), which typically takes 2 min (Hébert 1990). Ants do 


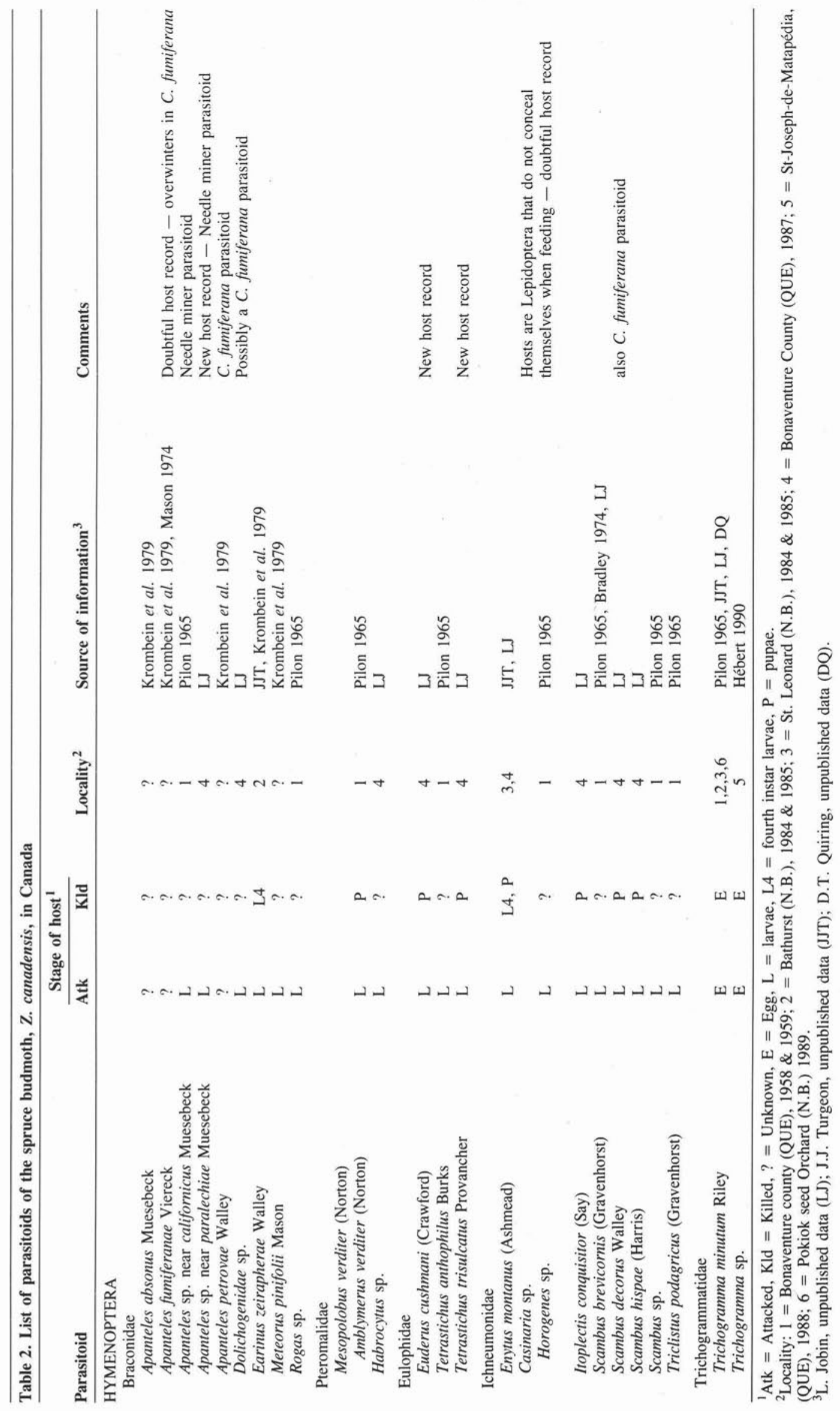


Table 3. List of predators of the spruce budmoth, Z. canadensis, in Canada

\begin{tabular}{|c|c|c|c|c|c|c|}
\hline \multirow[b]{2}{*}{ Predator } & \multicolumn{2}{|c|}{ Stage of host ${ }^{1}$} & \multirow[b]{2}{*}{ Locality $^{2}$} & \multirow[b]{2}{*}{ Source of information ${ }^{3}$} & \multirow{2}{*}{\multicolumn{2}{|c|}{ Comments }} \\
\hline & Atk & Kld & & & & \\
\hline \multicolumn{7}{|l|}{ HYMENOPTERA } \\
\hline \multicolumn{7}{|l|}{ Formicinae } \\
\hline Camponotus pennsylvanicus (de Geer) & PP, & PP, & 1 & Pilon 1965 & Dire & ervation \\
\hline Camponotus (C) herculeanus (Linnaeus) & PP, P & PP, P & 2 & JJT & " & " \\
\hline Camponotus $(C)$ noveboracensis (Fitch) & PP, P & PP, P & 2 & JJT & " & " \\
\hline Formica (F) exsectoides (Forel) & PP, P & PP, P & 3 & DQ & " & " \\
\hline Formica $(F)$ fusca Linnaeus & PP, P & PP, P & 2,3 & JJT, DQ & " & " \\
\hline Formica glacialis Wheeler & PP, P & PP, P & 4 & Hébert $1990^{4}$ & " & " \\
\hline Formica subnuda Emery & PP, P & $\mathrm{PP}, \mathrm{P}$ & 2 & JJT & $"$ & $"$ \\
\hline \multicolumn{7}{|l|}{ Myrmicinae } \\
\hline \multicolumn{7}{|l|}{ Myrmica lobicornis fracticornis Emery } \\
\hline Myrmica rubra scabrinodis detrinodis Emery & PP, P & PP, P & 4 & Hébert 1990 & " & " \\
\hline Myrmica sp. & PP, P & PP, P & 2,3 & JJT, DQ & " & " \\
\hline
\end{tabular}

${ }^{1} \mathrm{ATK}=$ Attacked, KLD $=$ Killed, $\mathrm{PP}=$ pre-pupae, $\mathrm{P}=$ pupae.

${ }^{2}$ Locality: 1 = Bonaventure county (QUE), 1958 \& 1959. 2 = Bathurst (N.B.), 1984 \& 1985. 3 = Fredericton (N.B.), 1988, 4 = St-Joseph-de-Matapédia (QUE), 1988

${ }^{3}$ D. Quiring, Department of Forest Resources, University of New Brunswick, unpublished data (DQ); J.J. Turgeon, unpublished data (JJT).

${ }^{4}$ See Hébert 1990 for detailed list of potential predators caught in pitfall traps near St-Joseph-de Matapédia 1988.

not open cocoons, which contain the pre-pupa or the pupa, but several carabid species have been observed to do so (Carter 1988). Red mites were also observed on pupae and appeared to be responsible for their deaths.

1.4 Adults. Spruce bud moth adults have been found caught in spider webs (Pilon 1965). A life table is currently being constructed to identify and assess the relative importance of all factors affecting $Z$. canadensis mortality (Ostaff \& Quiring, pers. comm.).

2. Applied biological control. Behavioral studies have revealed the microhabitat of $Z$. canadensis larvae is a high humidity environment, potentially suitable for the survival of host-seeking nematodes (Turgeon 1985). The possibility of using entomogenous nematodes as biological agents against first- and second-instar larvae was thus investigated. Larvae feeding in shoots were highly susceptible to Heterorhabditis heliothidis (Khan, Brooks \& Hirschmann) when assayed in petri dishes, but no larval mortality occurred when nematodes were sprayed on $Z$. canadensis-infested trees using distilled water as a carrier (Turgeon and FinneyCrawley 1991). Subsequent research by Eidt and Dunphy (1991) revealed that significant reductions of spruce bud moth populations by host seeking nematodes were possible when Futura XLV, a commercial Bacillus thuringiensis (Berliner) formulation, was used as a carrier for a foliar spray of Steinernema carpocapsae (Weiser). The spray was applied on white spruce when most larvae were in the third instar. Results from soil drench treatments suggested that applications of nematodes to the soil may represent an additional control alternative (Eidt and Dunphy 1991).

In 1984, 11,500,000 females of the minute egg parasitoid, T. minutum, were released in a 1-ha plot infested with a moderate population (7 healthy eggs $/ 15 \mathrm{~cm}$ branch) of $Z$. canadensis in New Brunswick. This release and others carried out in 1985 in the same plot resulted in a significant increase in the level of egg parasitism, which reached 65-70\% (E. Kettela, Forestry Canada, Maritimes Region, pers. comm.). The potential of this tactic for spruce bud moth control is currently being reinvestigated in more detail.
3. Classical biological control. Parasitoids from Z. ratzeburgiana, $Z$. rufimitrana and $Z$. diniana are currently being collected in Europe and sent to Canada where their compatibility with $Z$. canadensis is being tested (Mills et al. 1987), and potential candidates for inundative releases are being identified (V. Nealis, Forestry Canada, Ontario Region, pers. comm.).

\section{(f) Silvicultural practices}

The spruce bud moth should not inflict damage to white spruce throughout the rotation period. Indeed, field observations suggest the existence of a possible relationship between tree height, or crown closure, and $Z$. canadensis infestation intensity. In open grown white spruce, MacAndrews (1927) observed that when white spruce were 1-3 m high, $Z$. canadensis was numerically dominant over $Z$. fortunana (Kearfott), whereas the reverse was true on trees 4-9 $\mathrm{m}$ high, and neither could be found on trees taller than $10 \mathrm{~m}$. While developing sampling schemes, Turgeon and Régnière (1987) found the highest densities of $Z$. canadensis in plantations where trees were between 1 and $3 \mathrm{~m}$ high. In these plantations, spruce bud moth densities were as high as 25 to 30 larvae/15 cm branch. Densities in adjacent plantations where crown closure was complete, 5-12 m high, rarely exceeded 0.75 larva/branch. These observations suggest that the spruce bud moth is more successful in small plantations or in plantations in which crown closure has not occurred. When I revisited the tallest of the plantations in the 1-3 m range 3 years later, the spruce bud moth densities had decreased to less than 1 larva/branch. Although the leaders of most trees were affected by the spruce bud moth, some plantations grew out of this "susceptible" period. Whether the damaged trees will be adequate for sawlog production and whether harvest will be delayed, remains to be determined, but it appears that correctly-timed pest management could reduce the impact of this pest.

Although models that rate stand susceptibility to $Z$. canadensis have not been developed yet, a preliminary analysis of some site, stand, and tree variables associated with differences in $Z$. canadensis damage intensity has been 
conducted in Quebec. The amount of nitrogen, phosphorus, potassium and organic matter found in the severely damaged section of a plantation was significantly lower than that of the lightly damage section, suggesting that spruce bud moth damage is related to site quality (Gagnon et al. in press). This analysis also provides valuable information on other factors that may predispose (previous use of the site, compaction, water stress, etc), incite (intensive reforestation, bud moth population levels in surrounding sites, etc), and contribute (need for economic return, white spruce shoot phenology, etc) to spruce bud moth attack (Boulet, in press) and could form the basis for rating stand susceptibility. Once hazard ratings (e.g., Hedden 1981) are established, the forest manager should be able to select less vulnerable sites and optimize host resistance while respecting the silvicultural requirements of white spruce (Stiell 1976). Trees planted offsite or on sites deficient in nutrients increase the breakdown and mobilization of nitrogen in soluble form in the current year foliage, which in turn increases the survival of some pests (White 1984).

Susceptibility of white spruce leaders to damage by $Z$. canadensis was assessed for 72 half-sib families in New Brunswick (Quiring et al. 1991). A significant amount of the variation in damage was attributable to half-sib family, although environmental factors were more important. Interestingly, trees in less susceptible families displayed better growth than ones in susceptible families, even in the absence of spruce bud moth, suggesting that selection for reduced susceptibility to $Z$. canadensis is compatible with current breeding program objectives. Several mechanisms, such as reduced oviposition and egg survival, asynchrony between egg hatch and bud burst, and perhaps differences in larval survivorship due to plant nutrition and the effect of natural enemies, may be involved in reducing susceptibility of white spruce to $Z$. canadensis. Interplanting partially resistant white spruce with a smaller proportion of susceptible ones represents a preventative control method that could reduce plantation susceptibility on a long-term basis (Quiring et al. 1991).

\section{Conclusions}

The successful implementation of integrated pest management systems (IPM) in plantations requires an awareness and a sustained commitment to solve a problem from foresters, scientists and managers (Carrow 1985). As a result of this awareness and commitment, a rather impressive amount of information needed for the development of an integrated approach to the management of $Z$. canadensis in white spruce plantations has been generated since 1982. This information includes:

- the identification of windows of opportunity for control

- the development of sampling schemes needed to estimate the density of the spruce bud moth, either for studies on population dynamics or on control efficacy

- the development of a phenological model to predict the time of hatching and adult emergence and to allow the proper timing of sampling or control operations

- the identification of the sex pheromone to detect the emergence of adults and to allow the proper timing for interventions on moths

- the identification of the phenological relationship between $Z$. canadensis and shoot development
- the description of damage categories, which reflect accurately the severity of the damage inflicted by the larvae on the leader on a plantation basis

- the identification of two control tactics effective in providing adequate leader protection. One of these tactics, the application of permethrin at the time of hatching prevents damage to the current year leader; whereas the application of fenitrothion shortly after adults emerge, reduces the number of eggs sufficiently (if populations are not excessively high or immigration of moths is low) to decrease the probability of damage to next year's leader.

With this information an initial strategy for the management of spruce bud moth in white spruce plantations can be proposed. The strategy could consist of monitoring adults with sex attractants and assessing corresponding larval populations in young white spruce plantations, especially in those established on sites deficient in nutrients or in regions with a history of severe infestations (e.g. eastern Canada and northeastern United States). When populations reach the level where they begin to affect the form and vertical growth of about $5-10 \%$ of the trees, suppression actions should be contemplated. Carrow (1985) identified three control tactics that warranted major research effort at the time. None of them - Bacillus thuringiensis, the egg parasitoid Trichogramma sp. or pheromone disruption - has been successful to date and investigations to identify additional management tactics are continuing because neither permethrin nor fenitrothion have been registered for use against the spruce bud moth. Thus, until additional tactics are identified, it is possible that an application of pesticides every other year could be sufficient to reduce larval or adult populations and to prevent leader damage. If correctly timed, and sufficient population reduction is achieved, this intervention could give trees one to several years to achieve crown closure, or reach a height that reduces susceptibility to this pest.

Because of the obvious shortcomings of this strategy, additional specific information needs for the development of an IPM system for the spruce bud moth in white spruce plantations include:

- a detailed analysis of the white spruce-spruce bud moth interactions

- to assess Z. canadensis impact - ecological and economic - on white spruce growth and yield, thus providing a basis for the development of a sub-model (or part of a model that would consider all aspects of white spruce management) simulating bud mothinfested stand dynamics during the rotation period

- to relate the effect of site quality, tree height and crown closure, provenance, diversity in tree species, size and age classes, and harvesting practices on $Z$. canadensis population levels, and use this information to develop methods to assess risk of damage and improve our ability to predict damage

- to establish guidelines for the selection of proper sites to plant the desired species and ensure that stress is minimized

- to examine the relationship between spruce bud moth densities and damage, and establish a reasonable economic threshold

- a detailed assessment of the importance, impact, and interactions of the natural enemy complex with 
information on how their dynamics and impact could be influenced by pesticide applications

- a search for additional environmentally acceptable control alternatives, because few, if any, new registrations of pesticides are likely to occur for spruce bud moth control in the foreseeable future.

As mentioned throughout the text, several of the needs identified above are currently being investigated and some answers should be available in the near future. Others will take longer. For example, the establishment of mixed plantations (i.e., susceptible and non-susceptible trees) for experimental purposes is now being planned (Quiring, pers. comm.), but the benefits will not be apparent for at least a decade. One must remember how long it took to develop B.t., the only alternative to the operational control of the spruce budworm with chemical insecticides.

Associated with the development of an IPM system for the spruce bud moth are constraints (Neilson 1985) related to the public's perception of pesticides in general and intensive forest management. Thus, forest managers must convince the public that today's integrated approach to pest management is a rational one based on risks, economics, aesthetics and long term sustainability of the resource. Unless these concerns are addressed and the problems associated with spruce bud moth management in white spruce plantations are solved, it will never be possible for forest managers to make informed pest management decisions in line with forest management objectives and to maintain the long-term health of the forest.

\section{Acknowledgements}

The suggestions and comments of P. de Groot and D. Quiring and two anonymous reviewers were appreciated.

\section{References}

Bonneau, G., R. Picher and D. Lachance. 1986. Insectes et maladies des arbres, Québec - 1985. Forêt Conserv. suppl. 52(10), $32 \mathrm{p}$.

Bordeleau, C., D. Guérin, L. Innes, D. Lachance and R. Picher. 1988. Insectes et maladies des arbres, Québec - 1987. Forêt Conserv. suppl. 54(10), 32 p.

Bordeleau, C., D. Guérin, L. Innes, D. Lachance and R. Picher. 1989. Insectes et maladies des arbres, Québec - 1988. Forêt Conserv. suppl. 56(1), $32 \mathrm{p}$.

Boulet, B. 1987. Programme de surveillance dans les plantations. p. 16. In: Insectes et maladies des arbres, Québec - 1986. Forêt Conserv. suppl. 53(10), 32 p.

Boulet, B. Caractéristiques des arbres et de la station en relation avec les attaques de Zeiraphera canadensis (Lepidoptera: Tortricidae), sur l'épinette blanche en plantation. Rev. Entomol. Qué. (in press).

Bradley, G.A. 1974. Parasites of forest lepidoptera in Canada. Part 1. Environ. Canada. Can. For. Serv. Publ. 1336. 99 p.

Carrow, J.R. 1985. Spruce Bud moth - A case history: Opportunities. For. Chron. 61: 247-251.

Carter, B.P. 1988. Predation of prepupae and pupae of the spruce bud moth, Zeiraphera canadensis Mut. and Free. (Lepidoptera: Tortricidae) in white spruce stands in New Brunswick. B.Sc.F. Dissertation, Dept. of For. Resour., University of New Brunswick, 39 p.

Delucchi, V., J.-P. Aeschlimann and E. Graf. 1975. The regulating action of egg predators on the populations of Zeiraphera diniana Guénée (Lep. Tortricidae). Bull. Soc. Entomol. Suisse. 48: $37-45$.
Drooz, A.T. (ed) 1985. Insects of Eastern Forests. U.S.D A., Forest Serv., Misc. Publ. No. 1426. Washington, D.C. 608 p. Eidt, D.C. and G.B. Dunphy. 1991. Control of spruce bud moth, Zeiraphera canadensis Mut. and Free., in white spruce plantations with entomopathogenic nematodes, Steinernema spp. Can. Entomol. 123: $379-385$.

Gagnon, R.R., G. Pelletier, B. Boulet et M. Chabot. Comparaison de deux secteurs d'une même plantation inégalement endommagés par Zeiraphera canadensis Mut. et Free. (Lepidoptera: Torticidae). Rev. Entomol. Qué. (in press).

Graham, S.A. and S.B. Knight. 1965. Principles of forest entomology. Fourth Edition. McGraw-Hill, N.Y., 417 p.

Hartling, L.K. 1981. A preliminary report on the spruce bud moth (Zeiraphera spp.). Forest Protection Ltd. report. Fredericton, N.B. Hartling, L.K. 1982. A summary of the 1982 spray program against the spruce bud moth (Zeiraphera spp.). Forest Protection Ltd. report, Fredericton, N.B.

Hébert, C. 1990. Biologie et contrôle naturel de Zeiraphera canadensis Mut. \& Free. (Lepidoptera: Tortricidae) dans la région de Matapédia, Québec. Rapport pour le Ministère de l'Energie et des Ressources du Québec. 61 p.

Hedden, R.L. 1981. Hazard-rating system development and validation: An overview. Pages 9-12 In: Hedden, R.L., S.J. Barras, and J.E. Coster, (Tech. Coord.) Hazard-rating systems in forest insect pest management: Symposium proceedings. U.S.D.A. For. Serv., Gen. Tech. Rep. WO-27. 169 p.

Helson, B.V. and M. Auger. Efficacy and timing of permethrin mist blower sprays for the control of first-instar larvae of the spruce bud moth, Zeiraphera canadensis Mut. \& Free. (Lepidoptera: Tortricidae). Can. Entomol. (In press)

Helson, B.V., P. de Groot, J.J. Turgeon and E.G. Kettela. 1989. Toxicity of insecticides to first instar larvae of the spruce bud moth, Zeiraphera canadensis (Lepidoptera: Tortricidae): laboratory and field studies. Can. Entomol. 121: 81-91.

Holmes, J.A. and E.A. Osgood. 1984. Chemical control of the spruce bud moth Zeiraphera canadensis Mut. \& Free. (Lepidoptera: Olethreutidae) on white spruce in Maine. University of Maine at Orono, Maine Agricultural Exp. Stn., Tech. Bull. 112, 21 p. Kettela, E.G. 1990. Spruce bud moth can be controlled with aerial applications of fenitrothion insecticide to adults. Forestry Canada - Maritimes Region, Tech. Note 225, 7 p.

Kingsbury, P.D. and D.P. Kreutzweiser. 1987. Permethrin treatments in Canadian forests. Part 1: Impact on stream fish. Pestic. Sci. 19: 35-48.

Kreutzweiser, D.P. and P.D. Kingsbury. 1987. Permethrin treatments in Canadian forests. Part 2: Impact on stream invertebrates. Pestic. Sci. 19: 49-60.

Krombein, K.V., P.D. Hurd Jr., D.R. Smith and B.D. Burks. 1979. Catalog of Hymenoptera in America North of Mexico. Smithsonian Institution press, Washington, D.C.

Lavallée, R. and J. Morissette. 1988. Note sur la comparaison des captures des adultes de Zeiraphera canadensis avec trois modèles de pièges Multi-Pher. Phytoprotection 69: 87-89.

Lavallée, R., J. Régnière and J. Morissette. 1988. Influence de la température et des précipitations sur le vol des mâles de Zeiraphera canadensis en plantations d'épinettes blanches. Phytoprotection 69: 99-103.

MacAndrews, A.H. 1927. Biological notes on Zeiraphera fortunana $\mathrm{Kft}$, and ratzeburgiana Ratz. (Eucosmidae, Lepid.). Can. Entomol. 59: 27-29.

Mackay, M.R. 1959. Larvae of the North American Olethreutidae (Lepidoptera). Can. Entomol. Suppl. 10, 338 p.

Magasi, L. 1982. Forest pest conditions in the Maritimes in 1981. Can. For. Serv., Inf. Rep. M-X-135, 33 p.

Magasi, L. 1983. Forest pest conditions in the Maritimes in 1982. Can. For. Serv., Inf. Rep. M-X-141, 41 p.

Magasi, L. 1984. Forest pest conditions in the Maritimes in 1983. Can. For. Serv., Inf. Rep. M-X-149, 49 p. 
Magasi, L. 1985. Forest pest conditions in the Maritimes in 1984. Can. For. Serv., Inf. Rep. M-X-154, 49 p.

Martineau, R. 1985. Insectes nuisibles des forêts de l'est du Canada. Rapp. Tech. de Foresterie 32F. Serv. Can. For., Marcel Broquet, $283 \mathrm{p}$.

Martineau, R. and G.B. Ouellette. 1965. Quebec Region. Ann. rep. Forest Insect and Disease Survey 1965. 38 p.

Mason, W.R.M. 1974. The Apanteles species (Hymenoptera: Braconidae) attacking Lepidoptera in the micro-habitat of the spruce budworm (Lepidoptera: Tortricidae). Can. Entomol. 106: 1087-1102.

McLeod, J.M. and J.R. Blais. 1961. Defoliating insects on field spruce in Quebec. Can. Dept. For., Bi-mon. Prog. Rep. 17(1): 2. Miller, C.A. 1950. A key to some lepidopterous larvae associated with the spruce budworm. Dominion Dept. Agric., Bi-mon. Prog. Rep. 6(1): 1 .

Mills, N.J., M. Rather and K. Kruger. 1987. Annual Project Report 1987. C.A.B. Intern. Inst. Biol. Control, European Stn, $40 \mathrm{p}$.

Mutuura, A. and T.N. Freeman. 1966. The North American species of the genus Zeiraphera Treitschke (Olethreutidae). J. Res. Lepidop. 5: 153-176.

Neilson, M.M. 1985. Spruce Bud moth - A case history: Issues \& constraints. For. Chron. 61: 252-255.

Pilon, J.G. 1965. Bionomics of the spruce bud moth Zeiraphera ratzeburgiana Ratz., (Lepidoptera: Olethreutidae). Phytoprotection 46: 5-13.

Prentice, R.M. (Comp.) 1965. Forest Lepidoptera of Canada recorded by the Forest Insect Survey. pp. 627-629. Can. Dept. For. Publ. 1142 .

Quiring, D.T., J.J. Turgeon, D. Simpson and A. Smith. 1991. Genetically-based differences in susceptibility of white spruce, to spruce bud moth larval feeding. Can. J. For. Res. 21: 42-47.

Régnière J., B. Boulet and J.J. Turgeon. 1988. A sequential sampling plan with two critical levels for the spruce bud moth, Zeiraphera canadensis, (Lepidoptera: Tortricidae) J. Econ. Entomol. 81: 220-224.

Régnière, J. and J.J. Turgeon. 1989. Temperature-dependent development of the immature stages of Zeiraphera canadensis (Lepidoptera: Tortricidae) and simulation of its phenology. Entomol. exp. appl. 50: 185-193.
Schooley, H.O. 1983. Observations of the spruce bud moth and the spruce bud midge on black spruce in Newfoundland. Can. For. Serv., Res. Notes 3(3): 16-17.

Silk, P.J., E.W. Butterworth, L.P.S. Kuenen, C.J. Northcott, E. Dunkelblum and E.G. Kettela. 1989. Sex pheromone specificity in two sympatric Zeiraphera species: Zeiraphera canadensis and Zeiraphera unfortunana in New Brunswick. J. Chem. Ecol. 15: 2435-2444.

Stiell, W.M. 1976. White spruce: Artificial regeneration in Canada. Can. For. Serv., Dept. Env., For. Manage. Inst., Inf. rep. FMR-X-85.

Turgeon, J.J. 1985. Life cycle and behaviour of the spruce bud moth, Zeiraphera canadensis, (Lepidoptera: Olethreutidae) in New Brunswick. Can. Entomol. 117: 239-1247.

Turgeon, J.J. 1986. The phenological relationship between larval of the spruce bud moth, Zeiraphera canadensis, (Lepidoptera: Olethreutidae) and white spruce in northern New Brunswick. Can. Entomol. 118: 345-350.

Turgeon, J.J. and J.R. Finney-Crawley. 1991. Susceptibility of 1st- and 2nd-instar larvae of the spruce bud moth, Zeiraphera canadensis (Lepidoptera: Tortricidae), to the entomogenous nematode Heterorhabditis heliothidis under controlled conditions. J. Invertebr. Pathol. 57: 126-127.

Turgeon, J.J. and G.G. Grant. 1988. Response of Zeiraphera canadensis, (Lepidoptera: Tortricidae: Olethreutinae) to candidate sex attractants and factors affecting trap catches. Environ. Entomol. 17: $442-447$.

Turgeon, J.J., N. Nelson and E.G. Kettela. 1987. Reproductive biology of the spruce bud moth, Zeiraphera canadensis, (Lepidoptera: Tortricidae: Olethreutinae) in New Brunswick. Can. Entomol. 119: 361-364.

Turgeon, J.J. and J. Régnière. 1987. Development of sampling techniques for the spruce bud moth, Zeiraphera canadensis, (Lepidoptera: Tortricidae). Can. Entomol. 119: 239-249.

Viktorovskaya, Ye. A. 1976. Ecological characteristics of Zeiraphera ratzeburgiana. Ratz. (Lepidoptera, Tortricidae). Entomol. Rev. 55: 37-39.

White, T.C.R. 1984. The abundance of invertebrate herbivores in relation to the availability of nitrogen in stressed food plants. Oecologia 63: 90-105.
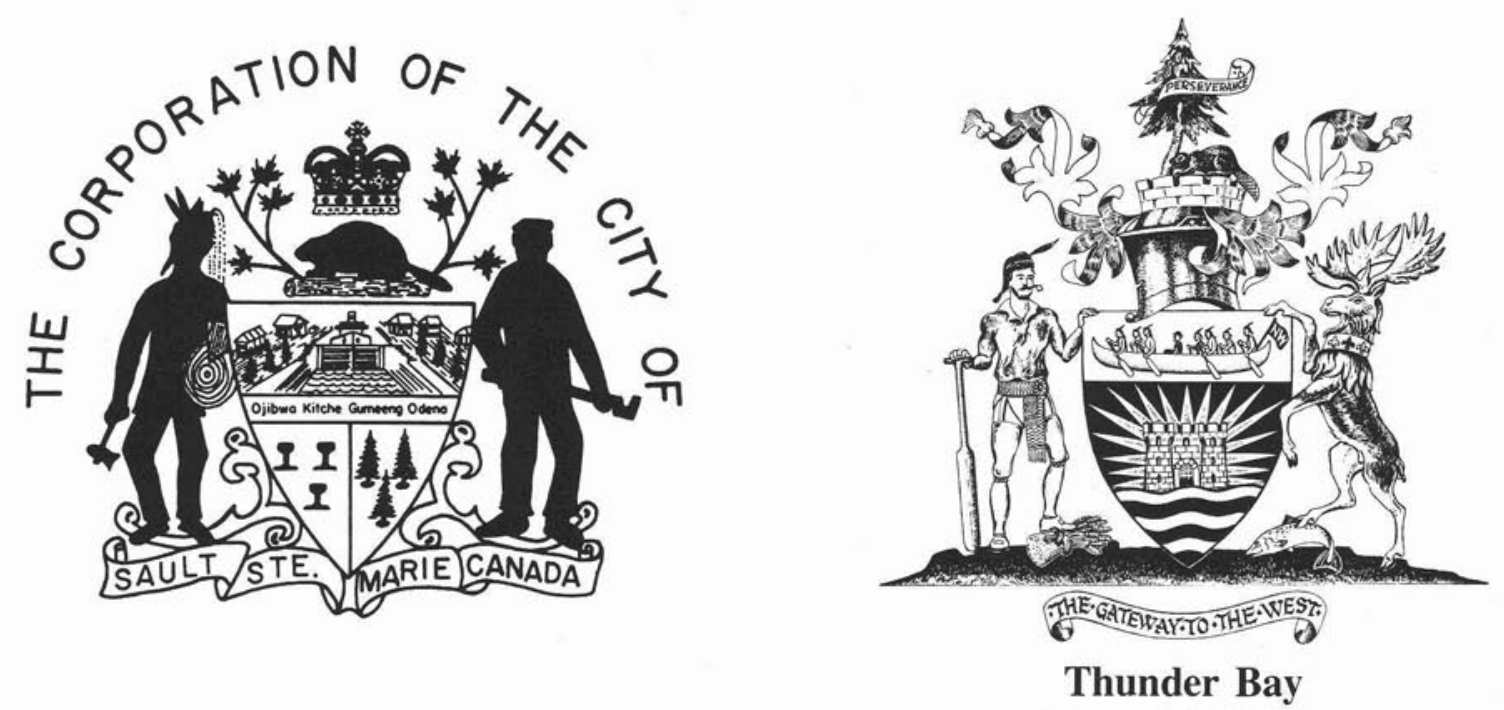

CIF/IFC Corporate Sustaining Members 